\title{
Review of Ayurvedic herbs with Kesharanjana Property in the Management of Caniites (Palitya)
}

\author{
Review Article
}

\author{
Murali Krishna $C^{1^{*}}$, Sivaram $G^{2}$, Malini $S^{3}$, Babu $G^{4}$ \\ 1. Research Officer, 2. Senior Research Fellow (Ayurveda), \\ 3. Research officer (Biochemistry), 4. Assistant Director In-charge, \\ Regional Ayurveda Research Institute for Skin Disorders, Vijayawada
}

\begin{abstract}
Greying of hair according to age is common phenomenon. But in modern era due to different kind of stress and changing life style Canities (Palitya) occur in early age. According to W.H.O in India, its incidence is high in the age group of 20-30 years. In Ayurveda premature greying of hair is called as Akala palitya (premature gray hair). According to Ayurveda grey hair is mainly due to the vitiation of Pitta dosha (biological entity related to exothermic reactions or transformation) \& reference of Palitya is directly mentioned only in Pitta Prakruti (inherent constitution of an individual). The use of purification procedures of panchakarma (detoxifying therapy) has prime importance in the remedies mentioned for premature greying. Nasya karma (nasal medication) is one of the major rejuvenative treatments. Palliative external \& internal medicaments measures like Shiro dhara (pouring oil on head), Shoro pichu (cloth dipped in oil kept on head), Shiro basti (oil is kept on head with an apparatus), Shiro lepa (application of medicated paste over head), Shiro abhyanga (oil massage to head) helps in speedy recovery. The chemical components in the herbs responsible for hair dyeing are discussed.
\end{abstract}

Keywords: Canities, Palitya, Kesaranjana, Hair dyeing, Ayurveda.

\section{Introduction}

Hair care is a part of trichology concerned with the nourishment, maintenance and prevention of diseases related to hair and scalp. It may involve colouring, trimming, and shaving or otherwise removal techniques such as waxing, threading and also postulates specific dietetics for healthy hair growth. The living parts of hair viz. hair follicle, hair root, root sheath, and sebaceous gland are beneath the skin, while the actual hair shaft which emerges (the cuticle which covers the cortex and medulla) has no living processes. Hair colour plays an important role in people's physical appearance and self-perception. As a matter of fact $90 \%$ of the world's population have deep brown-black hair. However, the remaining $10 \%$ of world population have blonde and auburn colour of hair possibly due to mutations in the melanocortin-1 receptor (MC1R), a G-protein coupled receptor. Considering the important role played by hair in social communication, premature hair graying or Canities has significant adverse effects on the appearance, selfesteem, and socio-cultural acceptance of the affected individual.

\section{*Corresponding Author:}

\section{Murali Krishna C}

Research Officer,

Regional Ayurveda Research institute for skin

disorders, Vijayawada-520015

Email: mkchagamreddy@gmail.com
A recent worldwide survey showed that $74 \%$ of people between the ages of 45 and 65 have Canities or grey hair (1). Hair is considered to grey prematurely only if it occurs before the age before 25 years in Asians (2). The colour of human hair depends on melanogenesis, the process of synthesis of melanin and its subsequent distribution from the melanocyte to keratinocyte. The process is thought to be regulated genetically at various levels. The human hair follicles contain two types of melanins, the black-brown pigment eumelanins mainly present in black and brown hair and the yellow or red pheomelanins in blonde hair and auburn (3). Both epidermal and follicular melanocytes are derived from immature melanoblasts that migrate from the neural crest into the skin during embryogenesis. As the hair follicle develops, the progeny of melanoblasts which proliferate in the epidermis, known as transient-amplifying melanocytes, leave that compartment and move into the developing hair follicle. There, melanocytes may become or remain DOPA-oxidase positive cells (i.e. express active tyrosinase) or remain DOPA-oxidase-negative cells depending on the intrafollicular compartment in which they reside (4).

Hair growth has three periods viz. Anagen Catagen \& Telogen. Anagen is the active or hair shaft growing phase of the cycle when the cells in the root of the hair divide at a rapid rate. Hair grows approximately $1 \mathrm{~cm}$ a month and can stay in this active phase of growth from anywhere between two and seven years. In Catagen stage hair growth stops and the outer root 
sheath shrinks and attaches to the root of the hair. It is the transitional part of the cycle where approximately $3 \%$ of all hairs are in this stage and only lasts for around two to three weeks. Telogen is the resting phase in the hair growth cycle when the hair follicle is completely inactive. Normally $6 \%$ to $8 \%$ of all hairs are in this stage, which tends to last about 100 days on the scalp (3). Senile Canities are believed to occur because of exhaustion of the regenerative capacity of hair pigmentation. Premature greying or Canities may reflect a genetically regulated early exhaustion of the melanocyte reservoir's seeding potential or some defect in cell activation/migration compounded by environmental factors, inflammation, or psychological stress (5).

\section{Ayurvedic View of Canities}

\section{Classification of Palitya (Canities)}

In Ayurveda greying of hair is called as Palitya, a type of kshudra roga (minor diseases). Ayurveda accounts for two types of grey hair viz. Akala palitya (premature grey hair) \& Kala palitya (senile grey hair). Premature grey hair is mainly caused by excess Ushna (hot) guna (property) of Pitta dosha (biological entity related to exothermic reactions or transformation) (6). Astanga hridaya text classified on the basis of dosha (biological entity) predominance viz. Vataja (biological entity related to movement), pittaja, kaphaja (biological entity related to structure or conglomeration), dwandaja (combination of two dosha) \& tri doshaja (all three dosha) (7).

Table No.1. Main four types of aetiological factors

\begin{tabular}{|c|c|c|}
\hline S.No. & \multicolumn{2}{|c|}{ Aetiological Factors } \\
\hline 1. & $\begin{array}{l}\text { Aharaja } \\
\text { (dietary) (8) }\end{array}$ & $\begin{array}{l}\text { - Excess intake of pungent (katu), sour (amla), salt (lavana), pungent (tikshna), } \\
\text { hot (ushna), light (laghu), pinyaka, kulathha (horse gram), mustard } \\
\text { (sarshapa), linseed (atasi), green vegetable (harita shaka), fish (matsya), goat } \\
\text { (aja), sheep (avika), curd (dadhi), takra (butter milk), kurchika, water of curd } \\
\text { (mastu), suravikara (type of sour alcohol) and amla phala (sour fruits), etc. } \\
\text { - Deficiency of Iron, Copper, vitamin B12, Calcium \&Vitamin D3. (9) }\end{array}$ \\
\hline 2. & $\begin{array}{l}\text { Viharaja } \\
\text { (life style) (8) }\end{array}$ & $\begin{array}{l}\text { - Over indulgence in physical exercise, exertion, awakening during night. } \\
\text { Excessive exposure to sunlight, smoking, intake of vitiated air and fast } \\
\text { (upavasa). }\end{array}$ \\
\hline 3. & $\begin{array}{l}\text { Manasika } \\
\text { (Psychological) (8) }\end{array}$ & $\begin{array}{l}\text { - Excessive anger (Krodha), grief (shoka), fear (bhaya) and mental stress } \\
\text { (mansika shrama). }\end{array}$ \\
\hline 4. & $\begin{array}{l}\text { Adibalapravritta } \\
\text { (Genetical) (10) }\end{array}$ & $\begin{array}{l}\text { - May occur alone as an autosomal dominant condition or in association with } \\
\text { various autoimmune or premature aging syndromes. } \\
\text { - sequence corresponds to all or part of a human chromosome } 6 \text { gene selected } \\
\text { among the HLAG, NT_007592.445, NT_007592.446, NT_007592.506, } \\
\text { NT_007592.507, NT_007592.508, HSPAIB, G8, NEU1, NG22, BAT8, HLA- } \\
\text { DMB, HLA-DMA, BRD2, HLA-DQA1, HLA-DQA2, NT_007592.58,, } \\
\text { GRM4, RNF23, FLJ22638, NT_007592.459 and NT_007592.457 genes. } \\
\text { - Sequence corresponds to all or part of the human chromosome } 9 \text { gene selected } \\
\text { among the FREQ, NT_030046.18, NT_030046.17, GTF3C5, CEL, CELL, FS, } \\
\text { ABO, BARHL1, DDX31, GTF3C4 and Q96MA6 genes }\end{array}$ \\
\hline
\end{tabular}

The above aetiological factors lead to vitiation of Pitta dosha. The Ushma (heat) of vitiated Pitta dosha is carried by vata dosha and lodging of kapha dosha in hair follicle will lead to paka (metabolic transformations) of hair follicle which in turn lead to A kala Palitya (premature grey hair) (11). In due natural course Kala palitya (senile grey hair) occurs as a general manifestation in old age.

\section{Ayurvedic Role in Kesaranjana (Hair Dyeing)}

Hair dyeing or colouring is a temporary process of adding pigment to or removing pigment from the hair shaft. Ayurvedic external medicaments play crucial role apart from nourishing nutraceutical supplements. Ayurvedic classics mentioned herbs, minerals \& metallic products for hair dyeing. According to Ayurveda hair dyeing procedure is not an instant process. Couple of days to months of treatment is required to achieve the desired results basing on the medicament. Eranda Herb (Ricinus communis L.) was used as colour fastness agent in most of the external hair dyeing formulations. Currently some famous Ayurvedic herbs as external and internal medication regarding grey hair are discussed viz. Haritaki, Vibhitaka, Amalaki, Bringaraja, Neeli, Madayantika, Akshota \& Patanga for dyeing hair to a deep dark colour. (Table No. 3) 


\section{Treatment protocol of Palitya}

Table No.2. Showing treatment protocol of Palitya

\begin{tabular}{|c|c|c|}
\hline S.No. & Treatment & Procedure \\
\hline 1. & $\begin{array}{l}\text { Sodhana } \\
(11,12) \\
\text { (Purification) }\end{array}$ & $\begin{array}{l}\text { - Vamana (medicated vomiting) } \\
\text { - Virechana (medicated purgation) } \\
\text { - Nasya karma of elimination type (nasal medication) } \\
\text { - Raktamokshana (bloodletting) }\end{array}$ \\
\hline 2. & $\begin{array}{l}\text { Samana } \\
(14,15,16) \\
\text { (Palliative) }\end{array}$ & $\begin{array}{l}\text { - Nasya for palliative care with oils like Prapaundrakadi tail, Mahanila taila, } \\
\text { Yashtimadhvadi taila, Chandanadya tail, Sahacharadi taila, Nimba taila, etc. } \\
\text { - Shiro dhara (pouring oil on head) with Bhringraj taila, Neeli taila, etc. } \\
\text { - Shiro pichu (cloth dipped in oil kept on head) with above said oils. } \\
\text { - Shiro basti (oil is kept on head with an apparatus) with above said oils. } \\
\text { - Shiro lepa (application of medicated paste over head) with yogas like Priyaladi } \\
\text { yoga, Tiladi yoga, Palithar yoga etc. }\end{array}$ \\
\hline 3. & $\begin{array}{l}\text { Rasayana (17) } \\
\text { (Rejuvenation) }\end{array}$ & $\begin{array}{l}\text { - Shiro bhyanga (oil massage to head) as a daily routine prevents premature } \\
\text { graying of hair. } \\
\text { - Internal usages of medicaments like Amalaki rasayana, Bhrungarajadi rasayana, } \\
\text { Siddhamakaradhwaja, Vasantakusumakara, Naradiya lakshmivilas rasa, } \\
\text { Narasimha Rasayana, etc. }\end{array}$ \\
\hline 4. & Preventive & $\begin{array}{l}\text { - Rasayana therapy with above said formulations. } \\
\text { - Avoiding the aetiological factors. } \\
\text { - Intake of wholesome dietetics with Pitta dosha balancing \& kesya (hair } \\
\text { nourishing) properties. } \\
\text { - Sadvritta (righteous code of conduct). }\end{array}$ \\
\hline
\end{tabular}

Table No.3. Showing some Ayurvedic herbs in useful in Canities (18)

\begin{tabular}{|c|l|l|l|l|l|}
\hline S.No. & Sanskrit Name & Botanical name & Family & $\begin{array}{l}\text { Dyeing } \\
\text { component }\end{array}$ & $\begin{array}{l}\text { Natural } \\
\text { Colour }\end{array}$ \\
\hline 1. & Haritaki & $\begin{array}{l}\text { Terminalia chebula } \text { Retz. } \\
\text { \& Willd. }\end{array}$ & Combretaceae & $\begin{array}{l}\text { Gallic acid, } \\
\text { Tannic acid }\end{array}$ & Yellow \\
\hline 2. & Vibhitaka & $\begin{array}{l}\text { Terminalia bellerica } \\
\text { Roxb. }\end{array}$ & Combretaceae & $\begin{array}{l}\text { Gallic acid, } \\
\text { Tannic acid }\end{array}$ & Yellow \\
\hline 3. & Amalaki & $\begin{array}{l}\text { Emblica officinalis } \\
\text { Gartn. }\end{array}$ & Phyllanthaceae & $\begin{array}{l}\text { Emblicanins, } \\
\text { ellagic acid }\end{array}$ & Yellow \\
\hline 4. & Bringaraja & Eclipta alba Hassk. & Asteraceas & Apigenin, & Yellow \\
\hline 5. & Neeli & Indigofera tinctoria L. & Fabaceae & Indigotin, & Blue \\
\hline 6. & Madayantika & Lawsonia inermis L. & Lythraceae & $\begin{array}{l}\text { Hennotannic } \\
\text { acid }\end{array}$ & Orange \\
\hline 7. & Akshota & Juglans regia L. & Juglandaceae & Regianin & Brown \\
\hline 8. & Patanga & $\begin{array}{l}\text { Haematoxylon } \\
\text { campechianum } \text { L. }\end{array}$ & Caesalpiniaceae & Haematoxylin & Black \\
\hline
\end{tabular}

\section{Discussion}

Grey hair is considered as the most embarrassing features of the people and is also a major symptom of ageing. Premature greying of hair is rasa pradoshaja (vitiation of Chyle/ Plasma/ Lymph) which occur mainly due to vitiated pitta dosha. Pitta dosha has properties like slightly unctuousness (sasneha), hot (ushna), swift (tikshna), liquid (dravam), sour (amla), mobility (sara) and pungent (katu). In head and skin, there is bhrajaka pitta (Pitta biological entity related to lustre/glow of the skin), responsible for digestion of hair (palitya). Even though there are several types of Palitya the main biological entity involved is Pitta dosha. Following Ayurvedic health care protocols like ideal food habits, minimal anxiety and use of Rasayana medicaments, one can prevent premature greying and delay the normal greying of hair due to old age or hereditarily causes. Patient should undergo purification therapies which are performed by Vamana, Virechana, Nasya, Rakta mokshana, etc along with wholesome dietetics \& lifestyle as a preliminary step in treating Canities. Purification of body helps to maintain the balance in dosha by which the 
palliative external \& internal medications work effectively.

As per the chemical constituents in the above mentioned herbs the active ingredient responsible for hair dyeing are discussed. The fruit of Haritaki \& Vibhitaka herbs contains Tannic acid \& gallic acid. Tannic acid is a specific form of tannin, a type of polyphenol useful as a yellow dye for hair. It is also a common mordant (dye fixative) used in the dyeing process. Gallic acid forms a complex with iron ions in hair to achieve a good chromaticity and fastness of the dyed hair. Emblicanins \& Ellagic acid in Amalaki herb are a type of polyphenol which are traditionally used as dyes. Presence of yellow crystalline flavones Apigenin and Luteolin in Bringaraj herb is the main reason for its dyeing property. Luteolin is also present in Neeli herb. Indigo dye is an organic compound with a distinctive blue colour extracted from the leaves of Neeli herb. The leaves were soaked in water and fermented to convert the glycoside indican present in the plant to the blue dye indigotin. Lawsone (2-hydroxy-1,4naphthoquinone), also known as hennotannic acid, is a red orange dye present in the leaves of Madayantika herb used for hair dyeing. Akshota herb contains Regianin, also called 5-hydroxy-1,4naphthalenedione is an organic compound having the tendency to create dark brown stains to hair. Haematoxylin is a black colouring compound present in the heart wood of the Patanga herb useful in dyeing hair.

\section{Conclusion}

The concept of Palitya (Canities) has been explained clearly in the lexicons of Ayurveda. Treatments like purification, palliative care, external applications, internal medications \& also preventive aspects of Canities have been suggested which are effective, natural \& without any side effects.

\section{References}

1. Panhard S, Lozano I, Loussouarn G (2012) Greying of the human hair: a worldwide survey, revisiting the '50' rule of thumb. Br J Dermatol 167: 865-73.

2. Tobin DJ (2008) Human hair pigmentationbiological aspects. Int J Cosmet Sci 30: 233-57.

3. Tobin DJ, Paus R. Graying: Gerontobiology of the hair follicle pigmentary unit. Exp Gerontol 2001;36:29-54.

4. Tobin DJ, Bystryn JC. Different populations of melanocytes are present in hair follicles and epidermis. Pigment Cell Res 1996;9:304-10.

5. Nishimura EK, Granter SR, Fisher DE. Mechanisms of hair graying: Incomplete melanocyte stem cell maintenance in the niche. Science 2005; 307:720-4.

6. Agnivesh, Charakasamhita, Chikitsasthan Trimarmiyadhyay 26/262, Vaidya Jadavaji Trikamji Aacharya. editor. 5th ed. Chaukhamba Sanskrit Sansthan, Varanasi; 2009; 676.

7. Vagbhat, Ashtang Hridaya, UttarSthan Shirorogavigyaniyadhyay 23/29, edited by Brahmanand Tripathi, reprint ed. Chaukhambha Sanskrita Pratishthana, Delhi; 2003; 1054.

8. Susruta, Susruta Samhita, Sutra Sthana vranaprashniyadhyaya 21/21, editor Vaidya Jadavji Trikamji Acharya, $8^{\text {th }}$ ed. Choukhambha Orientalia, Varanasi, 2005; 91.

9. Cutaneous manifestation of nutritional deficiency in current opinion of pediatrics health, M.L. Sidzury R, 2006 August; 18(4): 417-22.

10. BARSH G S, The genetics of pigmentation: from fancy genes to complex traits, Trends in genetics, elsevier science publishers, b.v. amsterdam, NL, vol. 12 , no. 8,$1 ; 1996$. p. 299-305.

11. Agnivesh, Charakasamhita, chikitsasthan, Tri marmiya chikitsadhyaya, 26/132, Vaidya Jadavaji Trikamji Aacharya. editor. 5th ed. Chaukhamba Sanskrit Sansthan, Varanasi; 2009; 509.

12. Agnivesh, Charakasamhita, chikitsa sthana Trimarmiya chikitsadhyay 26/262, Vaidya Jadavaji Trikamji Aacharya. editor. 5th ed. Chaukhamba Sanskrit Sansthan, Varanasi; 2009; 540.

13. Agnivesh, Charakasamhita, chikitsasthan Trimarmi -ya chikitsadhyay 26/263,264,269-275,277, Vaidya Jadavaji Trikamji Aacharya. editor. 5th ed. Chaukhamba Sanskrit Sansthan, Varanasi; 2009; 541, 542, 543.

14. Vagbhat, Ashtang Hridaya, sutrasthan 2/8, edited by Brahmanand Tripathi, reprint ed. Chaukhambha Sanskrita Pratishthana; Delhi; 2003; 26.

15. Agnivesh, Charakasamhita, sutrasthan Matrashitiyadhyay 5/81,82, Vaidya Jadavaji Trikamji Aacharya. editor. 5th ed. Chaukhamba Sanskrit Sansthan, Varanasi; 2009; 124.

16. Vagbhat, Ashtang Hridaya, sutrasthan Gandushadividhimadhyaya 22/34, edited by Brahmanand Tripathi, reprint ed. Chaukhambha Sanskrita Pratishthana; Delhi; 2003; 303.

17. Govind Das, Bhaishajyaratnavali, Commentary by Ambicadutt sastry, Rasayanadhikara $73 / 11,13,25,29, \quad 8^{\text {th }}$ Edition, Chaukhamba Surbharati Prakashan, Varanasi, 2007. p. $1103,1104$.

18. Pandey S N, S. N. Pandey, Ajanta Chadha, A text book of botany: Plant Anatomy and Economic Botany, Volume 3, Reprint Edition; 2009; 533-546. 